\title{
Parallel Implenetation of the GPR Techniques for Detecting and Mapping Ancient Buildings by Using CUDA
}

\author{
M. Cihat Mumcu ${ }^{1 *}$, Salih Bayar ${ }^{2}$ \\ ${ }^{1}$ Marmara Üniversitesi, Mühendislik Fakültesi, Elektrik Elektronik Bölümü, İstanbul, Türkiye (ORCID: 0000-0001-8097-7214) \\ 2 Marmara Üniversitesi, Mühendislik Fakültesi, Elektrik Elektronik Bölümü, İstanbul, Türkiye (ORCID: 0000-0002-4600-1880)
}

(Bu yayın 26-27 Haziran 2020 tarihinde HORA-2020 kongresinde sözlü olarak sunulmuştur.)

(DOI: 10.31590/ejosat.780115)

ATIF/REFERENCE: Mumcu, M. C. \& Bayar, S. (2020). Parallel Implenetation of the GPR Techniques for Detecting and Mapping Ancient Buildings by Using CUDA. European Journal of Science and Technology, (Special Issue), 352-359.

$\ddot{O} \mathbf{z}$

Yere nüfuz eden radar (GPR), bir duvarın arkasına gizlenebilen veya duvarın içine yerleştirilebilen nesnelerin algılanması için kullanılan ultra geniş bantlı bir elektromanyetik sensördür. GPR yöntemi, arayüzde yer alan yüksek hızda bir anten tarafindan yatay yönde yeraltına gönderilen elektromanyetik dalgaların, yine alıcı tarafından yatay yönde yansıtılmasının kaydedilmesi prensibi üzerine çalışır. Gömülü yapılar; toplanan veriler, bilgisayar programları ve çeşitli filtreler kullanılarak algılanır. Hava cepleri gibi duvarlar arasında gizlenmiş hedeflerin bulunması arkeologlara yardımcı olur. Bu çalışmada, toprağın dağılımı için Lorentz modeli kullanılmıltır. Sınır koşullarını sönümleyip açık bir alanı simüle etmek için mükemmel uyumlu katman (PML) kullanılmış ve dağıtıcı medyaya uyacak şekilde genişletilmiştir. Sonlu farklı zaman alanı (FDTD) yöntemi, elektromanyetik alanların zaman basamaklamasındaki kısmi diferansiyel denklemleri ayrıştırmak için kullanılır. FDTD hesaplaması çok yavaş çalışmaktadır. Bu sorunu çözmek için grafik işlem biriminde (GPGPU) genel amaçlı programlama yapılabilmektedir. Bu çalışmada GPU'ya CUDA kullanılarak 3-B FDTD yöntemi uygulanmış ve 10 kat hızlanmıştır.

Anahtar Kelimeler: Sonlu fark zaman alanı (FDTD), Yere nüfuz eden radar (GPR), Mükemmel uyumlu katman (PML), Gömülü nesneler, Paralel Programlama.

\begin{abstract}
Ground-penetrating radar (GPR) is an ultra-wideband electromagnetic sensor used for the detection of objects which may be hidden behind a wall or inserted within the wall. The GPR method works on the principle of recording the reflection of electromagnetic waves sent to the underground at high speed from the interfaces by an antenna located in the horizontal direction, again by the receiver in the horizontal direction. Embedded structures are detected using collected data, computer programs, and various filters. Search for the presence of designated targets hidden between the walls, such as air pockets is help to archaeologists. In this work the Lorentz model was used for the distribution of the soil. The perfectly matched layer (PML) used for absorbing boundary conditions to simulate an open space and its expanded to match dispersive media. The finite-difference time-domain (FDTD) method is used to decompose partial differential equations for time cascading of the electromagnetic fields. FDTD calculation works very slowly. General-purpose programming can be done on the graphics processing unit (GPGPU) to solve this problem. In this work, the 3-D FDTD method was applied to the GPU by using CUDA and it was 10 times faster.
\end{abstract}

Keywords: Finite difference time-domain (FDTD), Ground penetrating radar (GPR), perfectly matched layer (PML), buried objects, Parallel Programming.

\section{Introduction}

Ground Penetrating Radar (GPR) is a useful and extensive research technique for detecting underground sub-surface layers and buried objects. High-frequency electromagnetic waves (between $10 \mathrm{MHz}$ and $3 \mathrm{GHz}$ ) are sent to the underground via a transmitting antenna, and radar grams created using the round-trip times of their reflections in the ground and underground structures are examined in high discrimination. The waves are sent underground in a center frequency, and this source frequency has great importance in the

\footnotetext{
* Sorumlu Yazar: Marmara Üniversitesi, Mühendislik Fakültesi, Elektrik Elektronik Bölümü, İstanbul, Türkiye, ORCID: 0000-0001-8097-7214, cihatmumcu@maltepe.edu.tr
} 
phenomenon of wave penetration depth, scattering and absorption in the environment. Besides, the dielectric permeability, electrical conductivity and magnetic permeability values of the underground materials have essential effects on the wave areas travelling underground. Considering all these reasons together, the nature of the GPR method is complicated, and interpretation difficulties arise, especially considering that the underground is significantly heterogeneous.

The usage areas of the GPR technique are widespread and applied on almost all shallow geophysical problems (stratigraphy, fault determinations, landslide, karstic space determinations, shallow groundwater aquifer surveys, etc.):

- Archaeological structures and cultural heritage,

- Engineering applications (pipelines research, tunnel highway and railway lines, building equipment and problems in the building, etc.),

- Unexploded military material and mine detection.

In addition to those, it has a wide range of applications in forensic and natural disasters, pollution and underground chemical fluid leaks detection, research on solid waste areas, mineral deposits detection, ore exploration and marble studies.

However, the natural situation undergrounds and very mixed properties especially in shallow environments, difficulties arising from the nature of the method, ecosystems having lost, scattered, wave-absorbing and emitting properties cause significant problems and misinterpretations in the way of interpretation. For this reason, numerical modelling of the underground feature of interest before starting research will provide a considerable benefit in terms of strengthening the presentation. The rapid increase in computer hardware and possibilities in recent years have also enabled the development of modelling techniques of the GPR method. Modelling of the GPR consists of single frequency models, time environment models, ray tracing, transmission and reflection techniques (transmission reflection), integral techniques (MOM - moments method) and discrete element methods. Finite-difference timedomain (FDTD) technique is the most popular among them and can be realized with the help of a desktop computer in a relative competence.

In this work, the CUDA implementation of 2D-FDTD modelling of GPR detection for archaeological excavations [1-7] is proposed. Section 2 gives a brief information about GPR modelling, the FTDT algorithms are presented in Section 3. In the following Section, the CUDA implementation of 2D-FDTD model is proposed. Data analysis and simulation results are summarized in Section 5. Finally, Section 6 concludes the work.

\section{GPR Modelling}

Since the geometry of embedded objects such as air pockets and clay walls is constant in the third dimension, electromagnetic wave propagation modelling of GPR detection can be analyzed the 2-D problem.

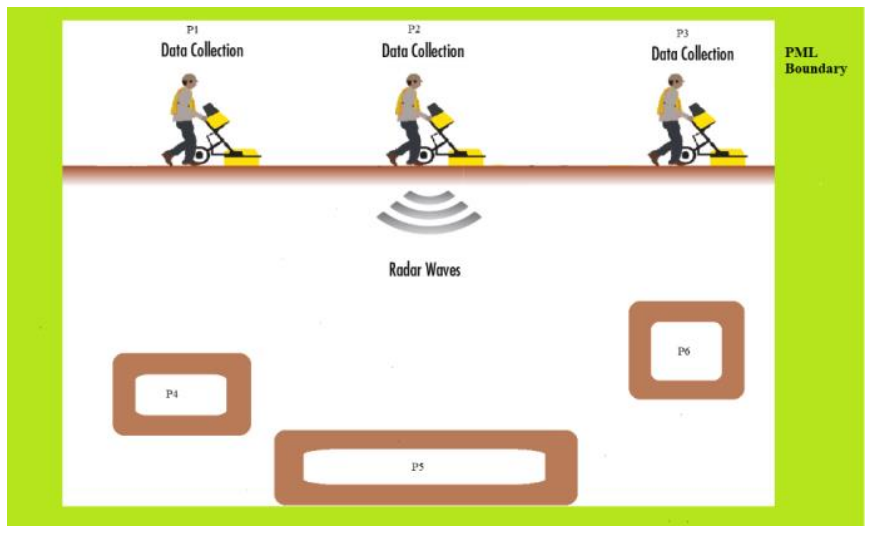

Fig. 1 The modelling of FDTD for GPR detecting of medium layers

On the ground, a transmitting source is placed in the middle of the soil surface. The horizontal and vertical distances of the medium are $7 \mathrm{~m}$. The medium has two layers, the upper side is air which thickness is $1 \mathrm{~m}$, and the lower side is soil whose width is $6 \mathrm{~m}$. Three different size rooms are buried at a depth of $3 \mathrm{~m}, 2 \mathrm{~m}$, and $4 \mathrm{~m}$ in the soil layer which has air pockets at its inside clay walls. The outer of the FDTD medium is perfectly matched layer (PML) boundary [8].

\section{FDTD Algorithms}

The FDTD algorithm allows analysis of all distribution types in one form. The Lorentzian algorithm is a frequently used distribution form and the polarization field in the frequency domain, $\mathrm{P}$

$$
P(w)=\frac{a}{b+j c w-d w^{2}}
$$

Shifting to the time domain with inverse Fourier Transform

$$
b P(t)+c P^{\prime}(t)+d P^{\prime \prime}(t)=a E(t)
$$


An essential step towards the formulized of a consistent and main FDTD algorithm is to approach the times derived from (2) the $\mathrm{n}-1$ time instantly. So, the following update equation is obtained:

$$
b P^{n-1}+c \frac{P^{n}-P^{n-2}}{2 \Delta t}+d \frac{P^{n}-2 P^{n-1}+P^{n-2}}{\Delta t^{2}}=a E^{n-1}
$$

or

$$
P^{n}=\frac{4 d-2 b \Delta t^{2}}{2 d+c \Delta t} P^{n-1}+\frac{-2 d-c \Delta t}{2 d+c \Delta t} P^{n-2}+2 \frac{2 a \Delta t^{2}}{2 d+c \Delta t} E^{n-1}
$$

can be written as

$$
P^{n}=C_{1} P^{n-1}+C_{2} P^{n-2}+C_{3} E^{n-1}
$$

The fixed $C_{1}, C_{2}, C_{3}$ values and can be found for any immersion relationship form. In the case of multipolar distribution, the same constant is written with three constants values for each pole.

Table 1. Dispersion Relation

\begin{tabular}{|c|c|c|c|}
\hline $\begin{array}{c}\text { Distribution term in } \\
\text { frequency domain }\end{array}$ & $\boldsymbol{C}_{\mathbf{1}}$ & $\boldsymbol{C}_{\mathbf{2}}$ & $\boldsymbol{C}_{\mathbf{3}}$ \\
\hline Lorentz Pole & $\frac{4 d-2 b \Delta t^{2}}{2 d+c \Delta t}$ & $\frac{-2 d-c \Delta t}{2 d+c \Delta t}$ & $\frac{2 a \Delta t^{2}}{2 d+c \Delta t}$ \\
$P=\frac{a}{b+j c w-d w^{2}} E$ & & \\
\hline
\end{tabular}

The Electric field intensity equation is given by;

$$
E^{n}=\frac{D^{n}-\sum_{i}^{N} P_{i}^{N}}{\varepsilon_{0} \varepsilon_{\infty}}
$$

Where $\mathrm{N}$ is the number of poles and $\mathrm{D}^{\mathrm{n}}$ electric flux density is attained using Yee's algorithm in Figure 2. The order in which the calculations are performed in the general algorithm is shown in the flowchart of Figure 3 [9].

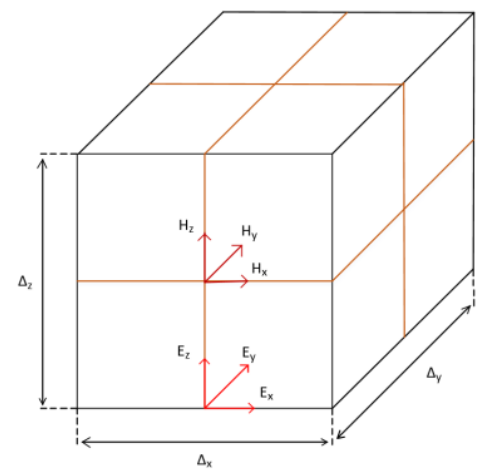

Fig.2 Discrete Yee Cellular of FDTD

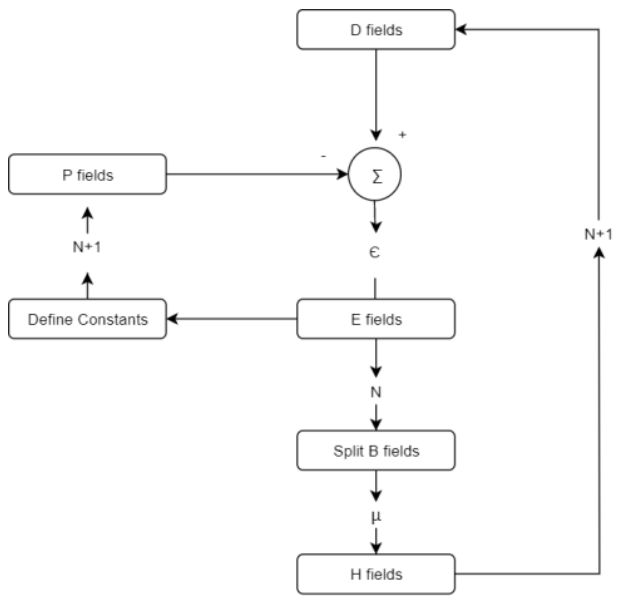

Fig. 3 Computations of General Algorithm 


\section{Realization of The FDTD Model on GPU}

The 3-D FDTD area is divided into two-dimensional planes. Figure 4 shows that the division of the $5 \times 5 \times 5$ structural FDTD area. FDTD equations for a given plane are resolved in parallel using a core on the GPU, however, all plane is calculated in a single time step, in turn, to the others, with its core invocation. The given all plane is converted into two-dimensional unit blocks, and therefore all blocks have standard CUDA parameters which blockIdx. $x$ and blockIdx.y. All block units are also divided into threads into two dimensions, so all threads have the standard threadIdx. $x$ and threadIdy. $y$ CUDA parameters. Figure 5 performs this decomposition method for the 3-D FDTD plane shown in Figure 4 [10-13].

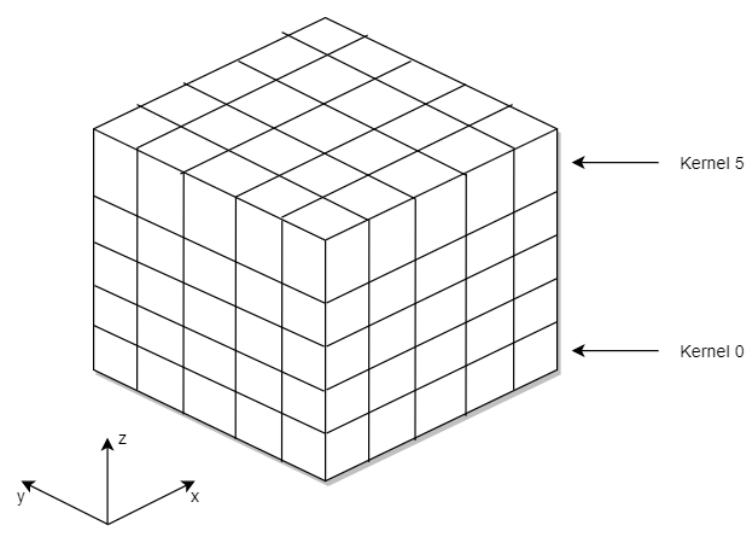

Fig. 4 Division of the three-dimensional FDTD space

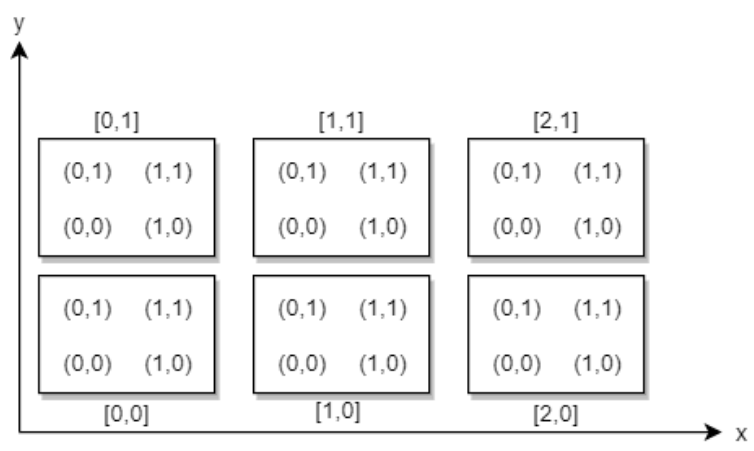

Fig. 5 Division of two-dimensional using blocks

Due to its simple algorithm and very high calculation efficiency in modern computers, the FDTD method is commonly used in the computational electromagnetic simulation [14]. The flow diagram in Figure 6 shows the operation of the FDTD method in the GPU. There are four main computation steps made at each time step in GPU side:

- E field computation (e_field),

- PML computation for E field (epml) as the absorbent boundary condition [15],

- H field (h_field) computation and,

- $\quad$ PML for H field (hpml).

All field updates in each time step can be parallelized and are offloaded to the GPU. 


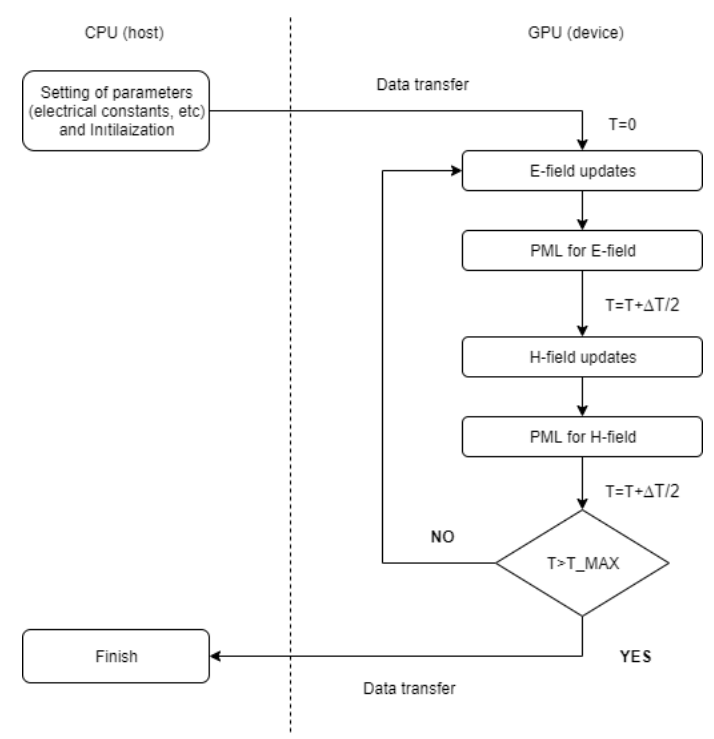

Fig. 6 FDTD computation flow chart

The original program which performs the 3-D FDTD algorithm was written in MATLAB and converted to CUDA code for performing its parallel calculation on the GPU. The computation process of the 3-D FDTD algorithm on the GPU starts with memory assignment, parameters definition and GPU setup. During the GPU setup part, memory assignment and defining of the variables allocated to the GPU are performed. In the next step, the information used in the computations of electromagnetic fields is transformed. In the FDTD algorithm operations performed on the GPU, so there is no data transfer process because all calculations are performed on the GPU [16-19].

\section{Simulation Results and Data Analysis}

First, calculation of five pole Lorentz equation parameters for 40\% moist soil are given in Equation 7 [20]

$$
\varepsilon_{n}(w)=\varepsilon_{\infty}+\left(\varepsilon_{s}-\varepsilon_{\infty}\right)+\sum_{p=1}^{5} \frac{G_{p} w_{p}^{2}}{w_{p}^{2}+j \delta_{p} w-w^{2}}
$$

where $40 \%$ moist soil parameters are;

$$
\begin{aligned}
& a=0.2 \varepsilon_{0}\left(\varepsilon_{s}-\varepsilon_{\infty}\right) w_{0}^{2} \\
& b=w_{0}^{2} \\
& c=2 \Delta \\
& d=10^{-25}
\end{aligned}
$$

where pole coefficients are given in Table 2. Simulation results of six receivers in different locations as shown in Figure 7.

Table 2. Dispersion Relation

\begin{tabular}{|l|c|c|c|c|}
\hline Pole Coefficients & $\boldsymbol{\varepsilon}_{\infty}$ & $\boldsymbol{\varepsilon}_{\boldsymbol{s}}$ & $\boldsymbol{w}_{\mathbf{0}}$ & $\boldsymbol{\Delta}$ \\
\hline First Pole & 13.7 & 15 & 15 & $9 \times 10^{-7}$ \\
\hline Second Pole & 13.7 & 25 & 15 & $1 \times 10^{-7}$ \\
\hline Third Pole & 13.7 & 26 & 15 & $1 \times 10^{-7}$ \\
\hline Fourth Pole & 13.7 & 33 & 11 & $6 \times 10^{-9}$ \\
\hline Fifth Pole & 13.7 & 25 & 17 & $6 \times 10^{-9}$ \\
\hline
\end{tabular}


To achieve high accuracy and acceleration performance of the FDTD method, we preferred to use a GPU. NVIDIA Quadro M1200 graphics card is utilized as the GPU with HP ZBook Workstation for the simulation platform. The cluster configuration is shown below. In the simulation process, a workstation is used for serial and parallel computing of the FDTD computation. The execution time of both serial and parallel computations are listed and compared in Table 3.

The data of the computation are listed in Table 3. As a result of the study, it was observed that FDTD calculation accelerated ten times with the use of parallel implementation on CUDA platform.

\author{
Simulation Platform \\ HP-ZBook 15 G41 \\ CPU: Intel (R) Core (TM) i7-7700HQ @ 2.80GHz (8 CPUs)
}

RAM:16 GB

Graphics Card: NVIDIA Quadro M1200

VRAM: 4 GB

Table 3. FDTD calculation and comparasion of different scenarios

\begin{tabular}{|l|c|c|}
\hline Calculation Method & Time(s) & CPU usagerate(\%) \\
\hline Serial & 2613.377 & 49 \\
\hline Parallel & 217.850 & 16 \\
\hline
\end{tabular}
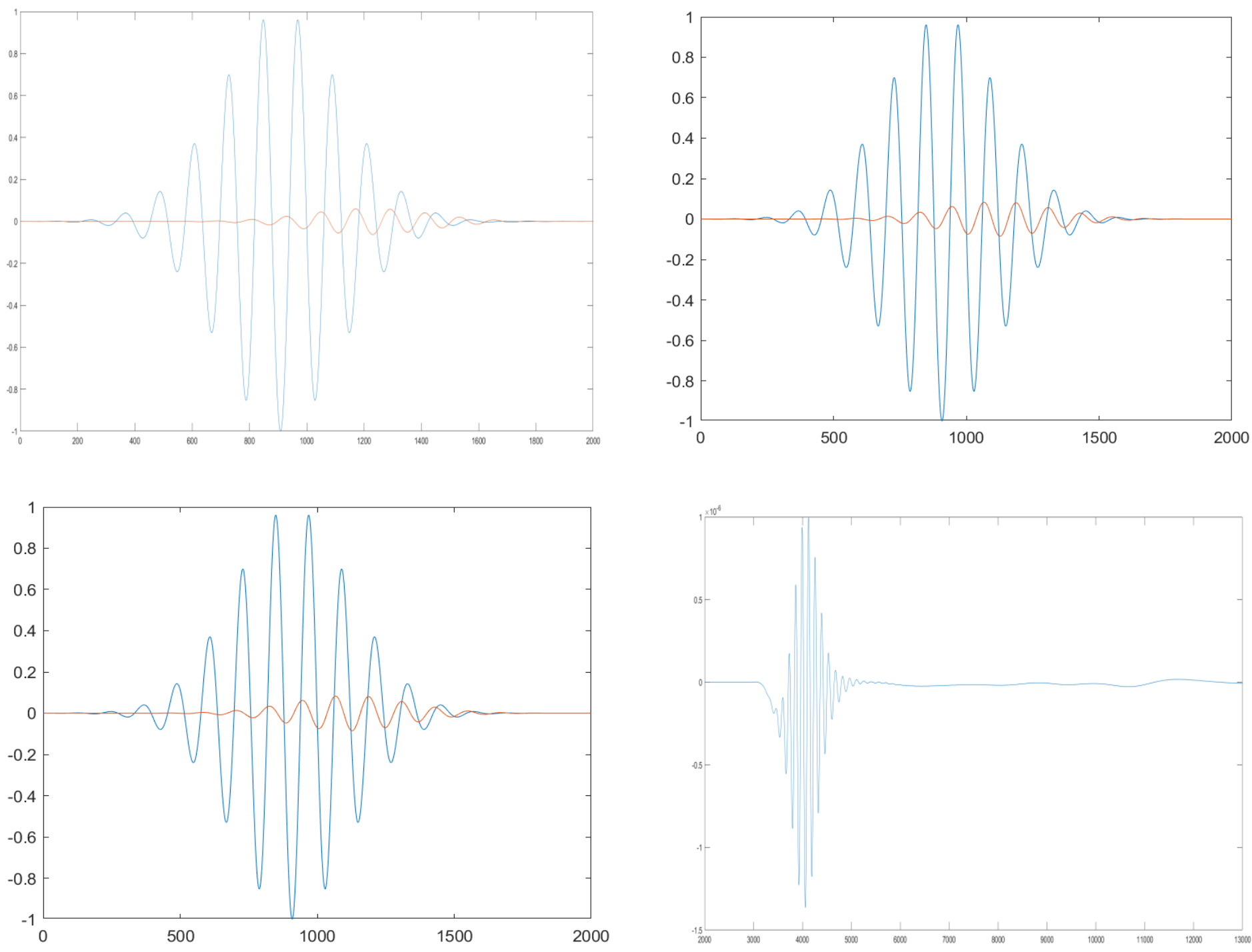

e-ISSN: 2148-2683 

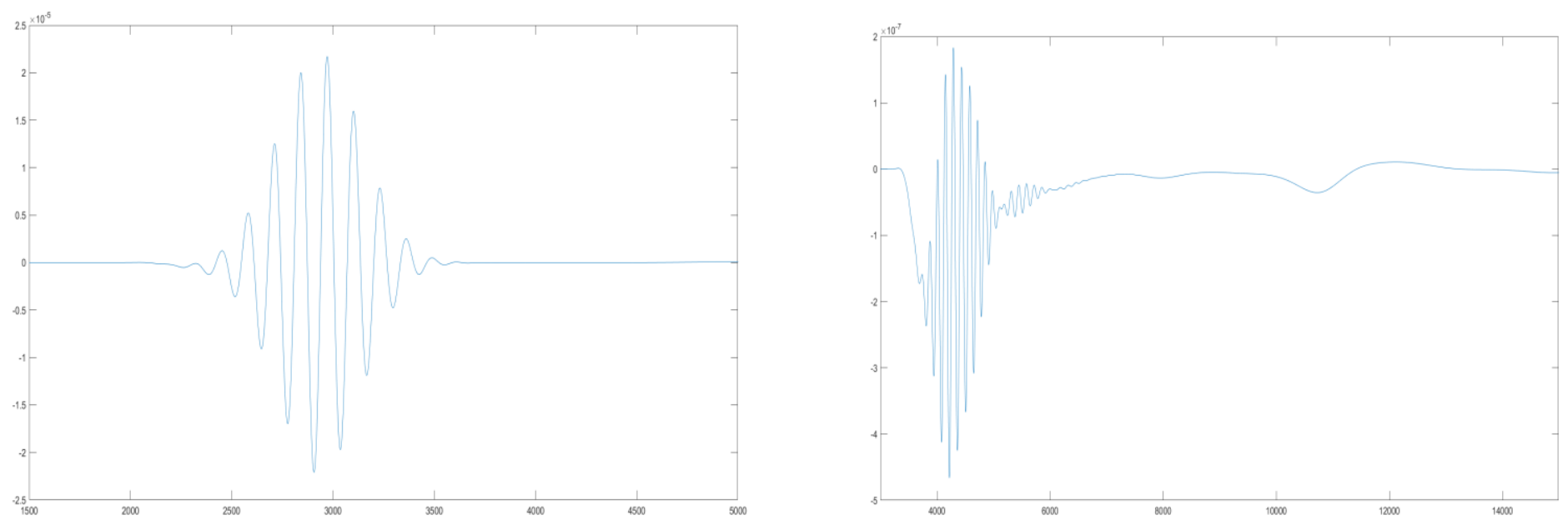

Fig. 7 Simulation Result of GPR Modelling

\section{Conclusion}

In this study, mathematical modelling and simulation of GPR systems for the detection of buried rooms are done using FDTD method, and CUDA implementation is carried out for performance improvement.

According to the results obtained, we can state that the parallel implementation of the GPR system is ten times faster than the serial implementation on CPU. This method helps to archaeologists to scan the ancient sites during archaeological excavations very fast.

\section{References}

[1] Klein, K.A., Santamarina, J.C.. "Electrical conductivity of soils: Underlying phenomena". Journal of Environmental and Engineering Geophysics, Vol. 8, No. 4, pp. 263-273, 2003.

[2] G. Alsharahi, A. Faize, A. Drioucach, A.M. Mostapha., "Determination of the Physical Properties and Geometric Shape of Objects Buried by Simulation Signals Radar GPR".8th International Conference on Modeling Simulation and Applied Optimization (ICMSAO), 2019.

[3] B. Burns., "Comparison of Measured Ground Penetrating Radar Response of Soil Surface to FDTD Model", IEEE International Symposium on Antennas and Propagation \& USNC/URSI National Radio Science Meeting, 2018.

[4] Liu Y., Guo L. X., Li Y. J., "FDTD Investigation on the Detection of Ground Rough Surface in GPR Modelling", International Conference on Microwave and Millimeter Wave Technology (ICMMT), 2018.

[5] S. Sesnic, A. Bradic, N. Bralic, F. Milicevic, M. Pastuovic, S. Vranjkovic., "FDTD Modeling of the Landmine Detection via Ground Penetrating Radar Response". 26th International Conference on Software, Telecommunications and Computer Networks (SoftCOM), 2018.

[6] Wei X.K., Wei S., Wang X.H., "Hybrid Sub-Gridded Time-Domain Method for Ground Penetrating Radar Simulations Including Dispersive Materials", IEEE Access, vol. 6, pp. 15777-15786, 2018.

[7] M. A. Alsunaidi, A. A. Al-Jabr, "An Efficient Time-Domain Algorithm for the Simulation of Heterogenous Dispersive Structures" Journal of Infrared, milimeter and Terahertz Waves, November 2009.

[8] Liu Y., Guo L. X., "FDTD Investigation on GPR Detecting of Underground Subsurface Layers and Buried Objects", IEEE MTT-S International Conference on NEMO.,2016.

[9] V. Myroshnychenko and C. Brosseau, " Finite-element modelling method for the prediction of the complex effective permitivity of two-phase random statistically isotropic heterostructures." Journal of Applied Physics, vol. 97, no. 4, 044101, Februrary 2005.

[10] M. Livesey, J.F. Stack, F. Costen, T. Nanri, N. Nakashima, and S. Fujino, " Development of a CUDA Implementation of the 3D FDTD Method", IEEE Antennas and Propagation Magazine, Vol. 54, No. 5, October 2012.

[11] J. Chi, F. Liu, E. Weber, Y. Li, and S. Crozier, "GPUAccelerated FDTD Modeling of Radio-Frequency Field- Tissue Interactions in High-Field MRI," IEEE Transactions on Biomedical Engineering, 58, 6, pp. 1789-1796, June 2011.

[12] Z. Bo, X. Zheng-hui, R. Wu, L. Wei-ming, and S. Xin-qing, “Accelerating FDTD Algorithm Using GPU Computing,” IEEE International Conference on Microwave Technology and Computational Electromagnetics, pp. 410-413, May 2011.

[13] D. A. Karavaev, V. V. Kovalevsky, "A Technique for Large-Scale 2D Seismic Field Simulations on Supercomputers", XIV International Scientific-Technical Conference on Actual Problems of Electronics Instrument Engineering (APEIE), 2018.

[14] T. Nagaoka, and S. Watanabe, "A GPU-Based Calculation Using the Three-Dimensional FDTD Method for Electromagnetic Field Analysis", 32nd Annual International Conference of the IEEE EMBS Buenos Aires, Argentina, August 31 - September 4, 2010.

[15] J.P. Berenger, "A perfectly matched layer for the absorption of electromagnetic waves," Journal of computational physics, pp. 185-200, 1994. 
[16] Y. Zhou, X. Duan, L. Zhou, Z. Luo, "Research on the Influence of CPU Power Management on the Performance of Parallel FDTD”, International Workshop on Electromagnetics: Applications and Student Innovation Competition (iWEM), 2019.

[17] D.A. Karavaev, V. V. Kovalevsky, "A Technique for Large-Scale 2D Seismic Field Simulations on Supercomputers" XIV International Scientific-Technical Conference on Actual Problems of Electronics Instrument Engineering (APEIE), 2-6 Oct,2018.

[18] A. Weiss, A. Elserbeni, V. Demir, M. Hadi, "Accelerating the FDTD Algorithm on CPUs with MATLAB's Parallel Computing Toolbox" International Applied Computational Electromagnetics Society Symposium (ACES), 2019.

[19] S. Ohnuki, R. Ohnishi, D. Wu, T. Yamaguchi, "Time-Division Parallel FDTD Algorithm", IEEE Photonics Technology Letters, Vol.30, Iss. 24, pp. 2143-2146, 2018.

[20] M. A. Alsunaidi, A. A. Al-Jabr, "A General ADE-FDTD Algorithm for the Simulation of Dispersive Structures.” IEEE Photonics Technology Lett., vol. 21, no. 21, pp. 817- 819, 2009 